\title{
PENGARUH KEPEMIMPINAN TRANSFORMASIONAL TERHADAP PENINGKATAN KINERJA PEGAWAI PEMERINTAH KECAMATAN KOTA SUMENEP
}

\author{
Rillia Aisyah Haris \\ Irma Irawati Puspaningrum \\ rilliaharis@gmail.com \\ irma.puspaningrum@gmail.com \\ Dosen Fakultas Ilmu Sosial Dan Ilmu Politik \\ Universitas Wiraraja Sumenep
}

\begin{abstract}
Abstrak
Kartono (2014:5) menjelaskan bahwa pemimpin menjadi faktor penentu sukses gagalnya suatu organisasi/institusi yang dipimpinnya. Hal ini menandakan bahwa keberadaan pemimpin menjadi faktor yang vital dalam menjalankan kelangsungan/kemajuan organisasi. Pemimpin yang berorientasi terhadap perubahan atau yang lebih dikenal dengan model kepemimpinan transformasional merupakan jawaban dari segala tuntutan organisasi untuk maju. Penelitian ini menggunakan metode kuantitatif untuk menganalisa pengaruh kepemimpinan transformasional terhadap peningkatan kinerja pegawai di kantor kecamatan kota Sumenep. Hasil penelitian menunjukkan bahwa berdasarkan uji $\mathrm{F}$ diketahui nilai sig $<\alpha$ mempunyai probabilitas lebih kecil dari 0,05 maka dapat disimpulkan bahwa $\mathrm{H} 1$ diterima dan $\mathrm{H} 0$ ditolak. Artinya bahwa keempat variabel independen secara bersama-sama (simultan) berpengaruh terhadap variabel dependen kinerja karyawan(Y). Rekomendasi yang dapat ditawarkan antara lain; membangun komunikasi efektif dengan para staf, menerapkan reward and punishment secara baik, optimalisasi kegiatan Monday Motifation dan Apel dalam upaya penyampai arahan/informasi dari Camat dan ide - ide / pendapat dari karyawan sebagai upaya peningkatan kinerja.

Kata kunci: kepemimpinan transformasional, kinerja, inovasi
\end{abstract}

\section{A. PENDAHULUAN}

Pemimpin yang berorientasi terhadap perubahan dikenal dengan model kepemimpinan

transformasional.

Pemimpin

transformasional menunjukkan

dukungan dan keyakinan dalam pekerjaan dan kontribusi nilai individual. Mereka memelihara dan mempromosikan pegawainya yang kreatif, menetralisir yang negatif, mengawasi sistem perusahaan secara keseluruhan dan tanggap dari segala perubahan kondisi untuk kemudian melakukan inovasi-inovasi menuju ke arah yang lebih baik (Hort, 2014). Untuk itu, kepemimpinan 
yang dikenal dengan transformasional ini jika dicermati dari penjelasan di atas sejatinya dalam rangka merubah dan memperbaiki suatu kondisi yang belum mapan, tidak baik, tidak berkualitas, dan memiliki stigma negatif menjadi berubah lebih baik dari sebelumnya.

Kecamatan Kota Sumenep terdiri dari empat kelurahan dan 12 desa. Kecamatan kota Sumenep sebagai barometer kecamatan lain di kabupaten Sumenep pada tahun 2014 yang lalu telah membuktikan keberhasilannya yaitu terpilih sebagai kecamatan terbaik dalam inovasi pelayanan publik kepada masyarakat di ajang Anugerah Madura Award. Kesuksesan pelayanan PATEN di Kecamatan Kota Sumenep merupakan komitmen serta kesungguhan camat dan pegawainya dalam menerapkan inovasi PATEN. Perbaikan kinerja sumber daya manusia yang dilakukan dengan peningkatan infrastruktur dengan tujuan memberikan rasa nyaman saat masyarakat mengurus dokumen di Kantor Kecamatan sangat diperhatikan oleh Camat Kota
Sumenep. Selanjutnya, Kecamatan Kota Sumenep telah memiliki front office yang nyaman dan dilengkapi dengan panel petunjuk serta alur pelayanan publik, sehingga memudahkan masyarakat yang mengurus dokumen di kantor Kecamatan kota.

Telah banyak terobosan yang dilakukan oleh Camat Kota Sumenep dalam rangka memberikan pelayanan terbaik kepada masyarakat. Salah satu inovasi yang dikembangkan Smart City dan elektonik PATEN. Dalam situs resmi Kabupaten Sumenep dijelaskan bahwa dalam mempersiapkan smart city, Camat dan pihaknya sudah memulai dengan melaksanakan Broadband Learning Center dan di setiap Desa di Kecamatan Kota sudah memiliki internet termasuk memberikan pelatihan kepada operator di Desa. Setiap operator desa telah memiliki website berekstensi go.id di bawah naungan Pemkab Sumenep dengan alamat ds-(nama desa di kecamatan kota).sumenep.go.id. Terobosan Kecamatan Kota ini dalam menfasilitasi jajaran di bawahnya memberikan indikasi bahwa salah 
satu faktor yang berpengaruh terhadap kinerja bawahannya adalah faktor kepemimpinan yang dilaksanakan oleh Camat Kota. Hal ini ditujukan untuk mengenalkan potensi wilayah masing-masing desa.

Berdasarkan prestasi dan profil singkat Kecamatan Kota Sumenep, peneliti tertarik untuk menelaah bagaimana kepemimpinan yang dilaksanakan oleh camat Kota Sumenep dalam meningkatkan kinerja pegawainya sehingga mampu mendapatkan prestasi Kecamatan Terbaik dalam Pelayanan Publik. Hal inilah yang melatarbelakangi penulis untuk meneliti lebih lanjut mengenai "Pengaruh Kepemimpinan Transformasional terhadap peningkatan Kinerja Karyawan di Kecamatan Kota Sumenep”.

B. TINJAUAN PUSTAKA

\section{Kepemimpinan}

\section{Transformasional}

Burns (1987) membedakan kepemimpinan transformasional dan kepemimpinan transaksional. Burns menjelaskan kepemimpinan sebagai arus antar hubungan yang berkembang, yang pemimpinnya secara terus menerus membangkitkan tanggapan motivasi pengikut dan memodifikasi perilaku pengikutnya pada saat menghadapi tanggapan atau perlawanan, dalam sebuah proses dan arus balik yang tidak pernah berhenti. (Soetari, 109;2014).

Bass memperkenalkan teori kepemimpinan transformasional yang dibangun berdasarkan gagasan awal dari Burns. Bahwa pengikut pemimpin transformasional merasa adanya kepercayaan, kekaguman, kesetiaan, dan rasa hormat terhadap pimpinannya dan bawahan tersebut termotivasi untuk melakukan leih daripada yang diharapkan darinya. Pemimpin mentransformasi dan memotivasi pengikutnya dengan cara (1) membuat pengikutnya lebih sadar mengenai arti penting sebuah pekerjaan yang dilakukan, mendorong pengikutnya untuk lebih mementingkan tim atau organisasi daripada kepentingan dirinya sendiri, (3) mengaktifkan kebutuhan pengikutnya pada level yang lebih tinggi (Soetari, 109;2014). Disampaikan pula oleh Bass bahwa kepemimpinan transformasi lebih meningkatkan motivasi dan kinerja 
pengikut dibandingkan dengan kepemimpinan transaksi, tetapi pemimpin yang efektif menggunakan kombinasi kedua jenis kepemimpinan. (Yulk,316;2015) Teori kepemimpinan Transformasional yang lain disampaikan oleh Yulk dalam Ancok (2012:126) bahwa secara umum kepemimpinan transformasional ini memiliki sifat memanusiakan pengikutnya, memperlakukan pengikutnya sebagai manusia cerdas dan terhormat, mampu 'mengeluselus' hati pengikutnya agar memunculkan potensi insaninya secara maksimal. Mereka juga mampu mendorong anggota untuk mengembangkan aspirasi dan memperoleh makna dalam bekerja, mampu mengembangkan pemimpinpemimpin baru di lingkungan kerjanya, menciptakan lingkungan kerja yang apresiatif sehingga bisa menggugah gairah dan semangat untuk berinovasi dan belajar bersama, menjadikan dirinya sebagai model strategi bagi anggotanya.

Secara lebih rinci, ciri-ciri kepemimpinan transformasional yang memacu inovasi dan kinerja dalam organisasi, menurut Ancok (2012:130-132) adalah sebagai berikut:

1. Pengaruh yang diidealkan (idealized influence)

Idealized influence adalah sifatsifat keteladanan yang ditunjukkan kepada pengikut dan sifat-sifat yang dikagumi pengikut dari pimpinannya. Perilaku yang dimunculkan, sebagai pemimpin lebih mengutamakan kepentingan karyawan dari pada kepentingan diri sendiri. Dia mau bersamasama dengan karyawan di dalam menanggung resiko dari keputusan yang diambil karyawan bersamanya.

2. Stimulasi intelektual (intellectual stimulation)

Dalam menunjukkan aspek intellectual stimulation, pemimpin mengajak pengikutnya untuk selalu mempertanyakan asumsi dibalik suatu hal, mencari cara baru dalam mengerjakan suatu hal. Pemimpin tidak mengkritik dan menilai gagasan yang dilontarkan. Dia lebih fokus 
pada pemberian apresiasi pada

setiap gagasan.

3. Kepedulian secara perorangan (individual consideration)

Individual consideration adalah

ciri pemimpin yang

memperhatikan kebutuhan

karyawannya dan membantu

karyawan agar mereka bisa maju

dan berkembang dalam karier

dan kehidupan mereka.

Pemimpin sangat

memperhatikan kebutuhan

psikososial karyawan yang

dipimpinnya. Pemimpin

menunjukkan rasa simpati pada

permasalahan yang dihadapi

pengikut dengan mencari jalan

untuk membantu

menyelesaikannya.

4. Motivasi yang inspirasional

inspirational motivation)

Inspirational motivation adalah

sifat pemimpin yang

memberikan inspirasi dalam

bekerja, mengajak karyawan

untuk mewujudkan sebuah cita-

cita bersama agar hidup dan

karya mereka menjadi

bermakna. Seorang pemimpin

memberikan kesempatan pada karyawan untuk menemukan kearifan dan mencari tantangan diri untuk berbuat sesuatu yang lebih baik.

\section{METODOLOGI}

1. Definisi Konsep dan

\section{Operasional}

\section{a. Variabel Bebas}

(Independen Variable)

Dalam penelitian ini yang menjadi variabel bebas yaitu Kepemimpinan transformasional (X), dengan variabel indikator :

1) Pengaruh yang diidealkan (idealized influence)

2) Stimulasi intelektual (intellectual stimulation)

3) Kepedulian secara perorangan (individual consideration)

4) Motivasi yang inspirasional (inspirational motivation)

\section{b. Variabel Terikat}

\section{(Dependen Variable)}

Adapun yang

menjadi variabel terikat yang digunakan dalam penelitian ini adalah Kinerja Karyawan 
(Y), dengan indikator sebagai berikut:

1) Kualitas kerja karyawan

2) Standar profesional

3) Kuantitas kerja

4) Kreativitas karyawan

\section{Pengukuran}

Pengukuran dilakukan dengan menggunakan skala Likert, yaitu apabila responden menjawab, maka nilai:

Kepemimpinan Transformasional dan kinerja karyawan dengan pengukuran :

$\begin{array}{ll}\text { 1. Sangat setuju } & 5 \\ \text { 2. Setuju } & 4 \\ \text { 3. Cukup } & 3 \\ \text { 4. Tidak setuju } & 2 \\ \text { 5. Sangat tidak setuju : } 1\end{array}$

\section{Populasi dan Sampel}

a. Populasi

Penelitian ini menggunakan pendekatan kuantitatif, maka populasi dalam penelitian adalah Pegawai di Kecamatan Kota Sumenep dalam keadaan tahun 2016 sebanyak 18 responden pegawai di Kecamatan Kota Sumenep.

b. Sampel
Teknik pengambilan sampling yang digunakan adalah Sampling Jenuh, artinya semua populasi dijadikan sampel.

\section{Analisis Regresi}

Penelitian ini menggunakan analisis regrsi linier berganda. Analisis ini berguna untuk menentukan hubungan sekaligus besarnya kontribusi setiap variable bebas terhadap variable terikat. Model matematis untuk alat analisis ini adalah sebagai berikut :

$$
Y=a+b_{1} x_{1}+b_{2} x_{2}+b_{3} x_{3}+b
$$

Dimana:

$$
\begin{aligned}
& \mathrm{Y}=\text { Peningkatan Kinerja } \\
& \mathrm{a}=\text { Konstanta } \\
& \mathrm{b}=\text { Koefisien arah regresi } \\
& \mathrm{X}_{1}=\text { Yang Diedialkan } \\
& \mathrm{X}_{2}=\text { Simulasi intelektual } \\
& \mathrm{X}_{3}=\text { Kepedulian Perorangan } \\
& \mathrm{X}_{4}=\text { Motivasi Yang }
\end{aligned}
$$

Inspirasional

\section{Uji Hipotesis}

1) Uji Regresi Secara Simultan ( Uji F)

$$
\text { Uji simultan (serempak) }
$$
digunakan untuk mengetahui apakah variable $(X 1, X 2, X 3, X 4, X 5)$ secara bersama-sama berpengaruh 
signifikan atau tidak terhadap variable tergantung ( $\mathrm{Y}$ ) untuk pengujian ini F-hitung akan dibandingkan dengan F-tabel pada derajat signifikansi $5 \%$. Bila Fhitung lebih besar dari F-tabel berarti secara bersama-sama variable bebas berpengaruh terhadap variable terikat dari uji serempak ini sekaligus dapat diketahui besarnya pengaruh variable-variabel terssebut secara bersama-sama dengan melihat koefisien determinasi $(\pi)$ Kecamatan Kota Sumenep, dengan perhitungan SPSS Versi 22.

Adapun dalam perhitungan ini menggunakan rumus dengan formula persamaannya sebagai berikut (Santoso, 2014: 295)

$$
\mathbf{Y}=\mathbf{a}+
$$

\section{bX}

Dimana :

$$
\begin{array}{lll}
\mathrm{Y} & =\text { Kinerja } \\
& & \text { Karyawan } \\
\mathrm{a} & = & \text { Konstanta } \\
\mathrm{bX} & = &
\end{array}
$$

Kepem impinan Transform asional
Kriteria penerimaan dan penolakan hipotesis, jika:

a. $t_{\text {hitung }}>\mathrm{t}_{\text {tabel}}$, atau signifikan $\leq 0.05$, maka hipotesis nol (H0) ditolak dan hipotesis alternatif (H1) diterima,

b. $t_{\text {hitung }} \leq \mathrm{t}_{\text {tabel }}$, atau signifikan >0.05, maka hipotesis nol (H0) diterima dan hipotesis alternatif (H1) ditolak.

2) Uji Regresi Secara Parsial (Uji-t)

Uji-t dilakukan untuk mengetahui kemaknaan pengaruh dari masing-masing variable bebas terhadap variabel terikat. Dari analisis ini sekaligus dapat diketahui besarnya kontribusi masing-masing variable bebas terhadap variable terikat, yaitu faktor regresi yang tersebar merupakan faktor yang berpengaruh dominan. Perhitungan dilakukan dengan cara membandingan nilai t dengan nilai ttest, pada derajat signifikan 5\% yang terdapat tabele analysis of variance dari hasil perhitungan dengan menggunakan program perhitungan SPSS Versi 22.

D. HASIL DAN PEMBAHASAN 
Menjadi pemimpin bukanlah hal yang mudah sebab sikap sikap kepemimpinan merupakan proses yang terus menerus dalam tahap menjadi pemimpin. Pemimpin yang sesungguhnya sering disebut sebagai pemimpin ideal , yaitu seorang pemimpin yang mampu menjalankan fungsi dan perannya, yang tidak lain adalah mengatur dan mengarahkan anggota organisasi. Berdasar hasil pengolahan data hasil penelitian yang telah diuraikan sebelumnya diketahui bahwa secara parsial (uji t) dengan variabel bebas yaitu pengaruh yang diidealkan (X1), stimulasi intelektual (X2), kepedulian secara perorangan (X3), motivasi yang inspirasional (X4), diketahui bahwa hanya (X2) yang berpengaruh sangat kuat terhadap peningkatan kinerja karyawan hal ini menunjukkan kepemimpinan transformasi dari faktor pengaruh stimulasi intelektual karyawan sangat mempengaruhi kinerja karyawan terutama bagaimana seorang pemimpin senantiasa memberikan aspirasi, ide dan gagasan pada karyawan dan bagaimana seorang pemimpin memfasilitasi pengembangan kompetensi karyawan.

Hal tersebut diatas sesuai sebagaimana disampaikan oleh Yulk dalam Ancok (2012:126) bahwa secara umum kepemimpinan transformasional ini memiliki sifat memanusiakan pengikutnya, memperlakukan pengikutnya sebagai manusia cerdas dan terhormat, mampu 'mengelus-elus' hati pengikutnya agar memunculkan potensi insaninya secara maksimal.

Dijelaskan pula oleh Burns bahwa kepemimpinan adalah sebagai arus antar hubungan yang berkembang, yang pemimpinnya secara terus menerus membangkitkan tanggapan motivasi pengikut dan memodifikasi perilaku pengikutnya pada saat menghadapi tanggapan atau perlawanan, dalam sebuah proses dan arus balik yang tidak pernah berhenti. Dikuatkan pula oleh pendapat Bass bahwa pengikut pemimpin transformasional merasa adanya kepercayaan, kekaguman, kesetiaan, dan rasa hormat terhadap pimpinannya dan bawahan tersebut termotivasi untuk melakukan leih 
daripada yang diharapkan darinya. (Soetari, 109;2014)

Walaupun terdapat beberapa dimensi kepemimpinan transformasional secara parsial tidak berpengaruh signifikan namun secara simultan (uji F) ke empat dimensi kualitas tersebut, yaitu dengan kesimpulan diperoleh dari perbandingan nilai sig dengan taraf signifikansi $(\alpha)$ adalah $(0,000)$ jadi dapat dilihat bahwa perbandingan nilai sig < a $(0,000<0,05)$. Karena nilai sig $<\alpha$ mempunyai probabilitas lebih kecil dari 0,05 maka dapat disimpulkan bahwa $\mathrm{H} 1$ diterima dan H0 ditolak. Artinya bahwa keempat variabel independen secara bersamasama (simultan) berpengaruh terhadap variabel dependen kinerja $\operatorname{karyawan}(\mathrm{Y})$.

Berdasarkan pada hasil penelitian diketahui bahwa dimensi kepemimpinan transformasional berpengaruh terhadap peningkatan kinerja karyawan di Kecamatan Kota Sumenep. Karena motivasi yang menginspirasi meliputi upaya mengaitkan tugas ke nilai dan prinsip para pengikut dalam hal ini karyawan dengan perilaku seperti

mengutaraka visi yang menginspirasi, bahwa seorang pemimpin bisa meningkatkan motivasi intrisnsik dengan meningkatkan persepsi pengikut bahwa sasaran tugas konsisten dengan nilai dan kepentingan mereka yang sebenarnya. Bahwa beberapa aspek kepemimpinan transformasi adalah relevan akan menimbulkan atau menguatkan pengaruhnya pada pengikutnya dalam penelitian ini adalah karyawan.

Dengan kepemimpinan tansformasional, para staf merasakan kepecayaan, kekaguman, kesetiaan, dan penghormatan terhadap pemimpin dan mereka termotivasi untuk melakukan lebih daripada awalnya diharapkan dari mereka. Menurut Bass kepemimpinan transformasional lebih meningkatkan motivasi dan kinerja pengikutnya dibandingkan dengan kepemimpinan transaksi, tetapi pemimpin yang efektif adalah menggunakan kombinasi kedua jenis kepemimpinan tersebut. (Yulk, 316:2015) 


\section{E. KESIMPULAN DAN SARAN}

Berdasar uraian analisis dan pembahasan penelitian, maka hasil penelitian ini dapat ditarik kesimpulan sebagai berikut :

1) Berdasar hasil perhitungan analisis regresi dari masingmasing Uji t dikenal dengan uji parsial, yaitu untuk menguji bagaimana pengaruh masingmasing variabel bebas secara sendiri sendiri terhadap variabel terikat. Dengan variabel bebas yaitu pengaruh yang diidealkan (X1), stimulasi intelektual (X2), kepedulian secara perorangan (X3), motivasi yang inspirasional (X4) adalah $\mathrm{H} 1$ diteima dan $\mathrm{H} 0$ ditolak jika nilai sign. $<0.05$. sedangkan pada tabel semua variabel X1, X3, X4 lebih dari 0,05. Maka artinya tidak ada pengaruh terhadap variabel y. Sedangkan x2 berpengaruh karena kurang dari 0,05

2) Berdasar hasil pengujian secara menyeluruh dari keempat dimensi secara simultan berpengaruh signifikan terhadap peningkatan kinerja karyawan hasilnya Uji $\mathrm{F}$ dikenal dengan uji serentak atau uji model/ uji Anova, yaitu diperoleh dari perbandingan nilai sig dengan taraf signifikansi $(\alpha)$ adalah $(0,000)$ jadi dapat dilihat bahwa perbandingan nilai sig $<$ a $(0,000$ $<0,05)$. Karena nilai sig $<\alpha$ mempunyai probabilitas lebih kecil dari 0,05 maka dapat disimpulkan bahwa H1 diterima dan H0 ditolak. Artinya, keempat variabel independen secara bersama-sama (simultan) berpengaruh terhadap variabel dependen peningkatan kinerja karyawan(Y).

Berdasarkan pembahasan dan kesimpulan hasil penelitian, maka penulis mengajukan saran sebagai berikut :

1) Hendaknya Camat memberikan keteladanan atau contoh yang baik kepada semua karyawannya terutama dalam hal kedisiplinan.

2) Komunikasi harus terjalin secara efektif antara Camat dengan semua karyawannya agar tercipta situasi dan kondisi yang menyenangkan dalam bekerja. 
3) Camat harus menerapkan pemberian reward kepada karyawan yang berprestasi dan memberikan punishment kepada karyawan yang melanggar aturan yang telah ditetapkan.

4) Optimalisasi kegiatan Monday Motifation dan Apel dalam upaya penyampai arahan/informasi dari Camat dan ide - ide / pendapat dari karyawan sebagai upaya peningkatan kinerja.

\section{F. REFERENSI}

Ancok, Djamaludin. 2012. Psikologi Kepemimpinan \& Inovasi. Jakarta: Penerbit Erlangga.

Arikunto,Suharsimi, 2010. Prosedur Penelitian Suatu Pendekatan Praktek, RinekaCipta Jakarta

Augusty, Ferdinand. 2006. Metode Penelitian Manajemen. Badan Penerbit Universitas Diponegoro, Semarang

Fahmi, Irham. Januari 2012. Kepemimpinan dalam Manajemen: Cet. Ke enam belas . Jakarta: PT. Raja GrafindoPersada.

Guritno, Bambang dan Waridin. 2005. Pengaruh persepsi karyawan mengenai perilaku kepemimpia,kepauasan kerja dan Motivasi terhadap Kinerja: JRBI
Nawawi,Hadawi. September 2006. Kepemimpinan mengefektifkan Organisasi. Cet. Kedua Gajah Mada Universitas Press. Yogyakarta

Markum Singodimedjo, 2005, Manajemen Sumber Daya Manusia, Penerbit Erlangga, Surabaya

Marpaung, Marudut. 2014. Pengaruh Kepemimpinan dan Team Work Terhadap Kinerja Karyawan di Koperasi Sekjen Kemdikbud Senayan Jakata. Jurnal http://ejournal.jurwidyakop3.co m/index.php/jurnalilmiah/aticel /donwload/163.142/ (diakses pada tanggal 16 januari 2018) Masambe, Fimce. Soegoto, Agus S. dan Sumarauw, Jacky. 2015. Pegaruh Gaya Kepemimpinan, Budaya Organisasi dan Inovasi Pemimpin Terhadap Kinerja Karyawan Daihasu Kharisma Manado. Jurnal. http://ejournal.com/2015/12/pe ngaruh-gayakepemimpinanbudaya.html (diakses pada tanggal 6 Januari 2018)

Pasolong, Harbani. Juli 2010. Kepemimpinan Birokrasi Cet. Kedua, Bandung Alfabeta

Yurk, Gary, 2015. Kepemimpinan Dalam Organisasi, edisi ketujuh. PT Indeks, Jakarta. 